\title{
CLYMENIA AND BURKILLANTHUS, NEW GENERA ALSO THREE NEW SPECIES OF PLEIOSPERMIUM (RUTACEAE-AURANTIOIDEAE)
}

\author{
Walter T. Swingle \\ With three plates
}

In CONNECTION with the preparation of a synopsis of the genera and species of the Orange Subfamily, Aurantioideae, that I have had under way for the past few years, a number of new species and a few new genera have come to light.

The striking new genera and new species here described show several new types of pulp-vesicles that throw much light on the origin and development of these remarkable organs peculiar to the subtribe Citrinae to which belong Citrus and the genera most closely related to it.

Attention has recently been directed to a very peculiar Citrus species commonly cultivated in New Ireland, an island about 360 miles northeast of New Guinea in the Bismarck Archipelago. It is called "a mulis" by the natives who eat the sweet fruits. Prof. T. Tanaka studied a herbarium specimen of this plant in the herbarium of the Botanical Museum at Berlin-Dahlem which was collected by Peekel, no. $408^{1}$ at Nukonuko, Namatanai, in New Ireland in 1910. In 1928, Tanaka published a new species, Citrus polyandra Tanaka, based on this specimen. He considered his new species as probably being a hybrid of the citron, $C$. medica, with the native bitter orange, C. macroptera, common in New Guinea and the western Polynesian Islands.

Upon examining a photograph of the type specimen, furnished me by Prof. Tanaka, I was struck by the fact that the leaves of $C$. polyandra are very unlike those of either of the supposed parent species in having very short wingless petioles, not articulated with the leafblades. Inasmuch as $C$. macroptera has very long, broadly winged petioles, sometimes nearly equalling the leafblade in area, it seems improbable that this species could be one parent of $C$. polyandra, especially since hybrids often found in the Philippines, between the commonly cultivated species of Citrus and C. macroptera, or related species belonging to the same group of Citrus (the subgenus Papeda with broadly winged petioles), always have petioles with wings intermediate in width between those of

${ }^{1}$ Tanaka, Tyozaburo, On certain new species of Citrus (in Studia Citrologia, Kankitsu Kenkyu, 2: 158-159 [Japanese], 163-164 [English and Latin]. Nov. 1928). 
the two parental species. I was also impressed with the fact that the leaves of $C$. polyandra show a remarkable resemblance to those of Monanthocitrus cornuta (Lauterbach) Tanaka, a Citrus relative native to New Guinea, but differing widely in other respects from $C$. polyandra. Thanks to the kindness of Dr. L. Diels, Director of the Botanisches Museum at Berlin-Dahlem, I have been able to make a critical examination of the leaves, flowers and fruits of $C$. polyandra. In the course of this study the only remaining flower bud on the unique type specimen was restored by a modification of Juel's method ${ }^{1}$, then imbedded and cut into serial sections. The bud, after imbedding, was first cut into longitudinal serial sections as far as the axis, then turned at right-angles and cut completely into numerous transverse serial sections. (Plate 1, figure 2.) These two sets of serial sections revealed characters very unlike those of Citrus, particularly in the androecium.

A section of dried fruit from the type specimen was also restored and cut into serial sections which showed that the pulp-vesicles, highly specialized structures found only in the subtribe Citrinae, differ decidedly in structure and still more strikingly in their mode of attachment, from those of any other plants of this tribe. Convinced by the study of this material that the plant from New Ireland was a striking new type of Citrus Fruit Trees, I wrote to Prof. Cyril T. White, F. L. S., Government Botanist of Queensland, Brisbane, Australia, requesting him to secure, if possible, more material for me. Through his good offices, the hearty cooperation of the Agricultural officers of the Mandate of New Guinea (of which New Ireland is a part) was secured and in May, 1937, Mr. G. S. Gee, with the help of Brother Peekel, who collected the type specimen of Citrus polyandra Tanaka, secured for me excellent material preserved in formaldehyde solution, showing flowering and fruiting twigs, mature leaves and ripe fruits. (Plate 1, figures 3, 4, 5.) A thorough study of this material proves that this plant constitutes a new genus closely allied to Citrus yet differing in many very important characters; for this genus I propose the name Clymenia.

\section{Clymenia 2 gen. nov.}

Clymenia, genus Citro affine sed differt vesiculis pulpiferis pyriformi-

${ }^{1}$ See Swingle, Walter T., New methods of restoring material in a study of Citrus and related genera. (in Jour. Wash. Acad. Sci. 29:218. 1939). In this work I have had the skilled assistance of Dr. Albert H. Tillson.

${ }^{2}$ From the Greek $\kappa \lambda v \mu \epsilon \dot{\nu} \eta$, a mythological Greek character, sometimes said to be the mother of Atalanta (for whom Correa da Serra named the genus Atalantia, a rather close relative of (itrus), but more often held to be either the daughter of the Titan, Oceanus, and mother of Atlas or else a consort of Jupiter and mother of the ill-fated Phaet on (see Bulfinch, Thos., Age of Fable, ed. E. E. Hale, pp. 49, 457, 467. 1881.) 
bus, sessilibus, non solum ad parietes dorsales loculorum fructus sed etiam numerosissimis ad parietes laterales $(2 / 3-3 / 4$ distantibus a centro) colligatis; staminibus numerosissimis (quindecies vel viginties quam petalis), liberis, in androphoro truncato-conico latiore quam ovario dispositis; stylo crasso, brevissimo, haud tam longo quam dimidio ovario; foliis simplicibus, petiolis brevissimis cum lamina non articulatis; nervis lateralibus numerosissimis, subparallelis.

Arbor parva, ramis inermibus, ramulis subangularibus; foliis simplicibus, nervis lateralibus numerosissimis (utrinque 20-30), petiolis brevissimis (quindecies vel decies brevioribus quam lamina folii); floribus solitariis in axillis foliorum nascentibus; pedicellis crassioribus et paulo longioribus quam petiolis foliorum subtendentium; disco parvo; filamentis liberis, filiformibus; ovario ovoideo, loculis 14-16, ovulis 4, uniseriatim in quoque loculo, stigmate depresso-capitato; fructibus ovoideis, fructu Citri similibus, cortice glandulis oleiferis punctato; seminibus numerosis, magnitudine seminis C. Limon, embryone unico.

Type species: Citrus polyandra, Tanaka in Studia Citrologica, 2: $163(1928)$.

Distribution: Known only from the type locality at Namatanai, New Ireland, Bismarck Archipelago.

This genus strongly resembles Citrus in its general aspect, but differs very strikingly in having simple leaves with more numerous, subparallel lateral veins (20-30 pairs, but not all equally prominent) ; completely wingless, very short petioles (less than $1 / 10$ as long as the leafblade); very numerous stamens (15-20 times as many as petals) borne in many rows on a truncate-conical androphore broader than the ovary; hypermerous ovary (14-16 locules), short style (about $1 / 2$ as long as the ovary), depressed capitate stigma; ovoid fruit, with very numerous short, broad, pyriform, sessile pulp-vesicles having the apex broadly rounded, attached both to the dorsal locule walls and to the radial walls for $2 / 3-3 / 4$ of the distance from dorsal wall to the axile angle of the locule.

The most striking character exhibited by this genus is its huge, broad, cork-shaped androphore that subtends the ovary and obviously exceeds it in diameter (Plate 1, figure 3). This androphore is not the disk, as Tanaka supposed, but the greatly swollen, truncate-conical, stamenbearing portion of the floral axis.

Although Clymenia is obviously closely related to Citrus and the other genera of the True Citrous Fruit Tree Group (Microcitrus, Poncirus, Fortunella and Eremocitrus) it is clearly distinct from any of them. Its nearest analogue in the genus Citrus is found among the bitter oranges belonging to the subgenus Papeda which also often has fruits with pulp-vesicles 
attached to the outer portions of the radial walls of the locules. However, the bitter oranges have very long, very broadly winged, clearly articulated petioles and the leafblades do not show numerous subparallel lateral veins.

Possibly the nearest relative of Clymenia is the anomalous Microcitrus inodora (Bail.) Swingle, indigenous to northern Queensland, which also has rather large, simple leaves with very numerous parallel lateral veins and very short, wingless petioles and very numerous (over 30) free stamens. However, $M$. inodora has slender-stalked pulp-vesicles like all the other species of Microcitrus, an ovary with only 8 locules and abundant spines, often paired. The leaves of Clymenia show a number of remarkably close resemblances to those of Monanthocitrus and Wenzelia, two genera of the Minor Citroid Fruit Trees (subtribe TriphasinnaE), usually considered rather distantly related to Citrus.

Clymenia may prove on close study of living material to represent a side-line of evolutionary development parallel to, but not in, the main line of descent of the True Citrous Fruit Tree Group. Only one species is known:

Clymenia polyandra (Tanaka) Swingle, comb. nov.

Plate 1

Citrus polyandra Tanaka in Studia Citrolog. 2: 163, [Japanese] pp. 160162. 1928.

Citrus medica subsp. Limonum var. Limetta sensu Lauterbach in Bot. Jahrb. 55: 264. 1918, non(Risso) Engl.

Twigs angular when young, glabrous, fruiting branches spineless (young plants possibly spiny) ; leaves simple, large, $12-18 \times 4-6.5 \mathrm{~cm}$., oblong-elliptical, more or less caudate-acuminate at the tip (acumen narrow, abruptly rounded), cuneate-attenuate at the base, subcoriaceous, glabrous, lateral veins subparallel, numerous (20-30 pairs), varying in visibility, about half of them easily seen and felt (only these stronger veins visible on upper surface), arising at an angle of $55-65^{\circ}$ with the midrib, margins minutely crenulate-serrate; petioles slender, wingless, very short, $6-12 \times 2-2.5 \mathrm{~mm}$., flattened on upper side and narrowly margined for a short distance at the tip where the leaf margins are slightly decurrent; flowers borne singly or in few-flowered cymose fascicles in the leaf axils; pedicels more or less angled, usually slightly longer than the petioles on mature flowers, $10-12 \mathrm{~mm}$. long, merging into the calyx and $3.5-4 \mathrm{~mm}$. wide at the top, tapering to $2-2.5 \mathrm{~mm}$. diam. at base; calyx 5-lobed, lobes very thick, rugose without, subtriangular; corolla imbricate (not seen except in the bud); disk inconspicuous, stamens very numerous, in several series, borne on a large truncate-conical androphore wider than the ovary; ovary truncate-conoidal, $3 \mathrm{~mm}$. wide at 
base, $2.5 \mathrm{~mm}$. at top, $3 \mathrm{~mm}$. high with 14-16 locules, each with 4 uniseriate ovules; style short ( $2 \mathrm{~mm}$. long with stigma) $1.3-1.5 \mathrm{~mm}$. wide, not merging into the ovary; stigma depressed-capitate, slightly broader than the style; fruits pyriform or subglobose, slightly mamillate at attached end, 6-8 $\times 5-6 \mathrm{~cm}$.; pulp-vesicles attached as described above under the genus, ovoid, pyriform, 3-4 mm. high, 2-3 mm. wide, narrowed below to only $1 / 3$ or $1 / 2$ of the maximum diam. where attached, but not slender-stalked; peel 3-4 mm. thick, dotted with numerous slightlydepressed oil-glands, yellow when ripe; stipe of fruit rigid, $5 \mathrm{~mm}$. diam. sometimes swelling to $7-8 \mathrm{~mm}$. just below the attachment which is about 6-7 mm. diam.

Bismarck Archipelago. New Ireland: Nukonuko, Namatanai, Peekel no. 408. Type in Herb. Bot. Mus. Berlin-Dahlem; fragment of type, Herb. Nat. Arboretum, Washington, sheet no. 46011; serial microtome sections, S. and T., slides 222 B, 1-6 (longitud. sect. ovary), 227 A, 1-17 (cross sect. of same bud), 300 A, 1-2 (pulp vesicles and locule walls), filed in type collection, Nat. Arboretum, Washington. Topotype: Buratamtabai, Namatanai, G. S. Gee, 5/6/37 (Herb. Na: Arboretum, sheet no. 46010).

Possible Uses: The fact that Clymenia bears a sweet fruit the size of a large lime, and is already cultivated by the Melanesian natives of New Ireland, makes it of unusual interest for trial as a new Citrus fruit tree. It will be very interesting to test Clymenia as a root-stock and make hybrids if possible, between it and the five other genera of the True Citrus Fruit Trees (Citrus, Microcitrus, Fortunella, Eremocitrus and Poncirus) both in the hope of securing new types of edible Citrus fruits and also new root-stocks for experimental tests.

\section{Burkillanthus, a new Genus remotely allied to Pleiospermium}

In 1893 a remarkable tree was discovered in the Territory of Malacca, Malay Peninsula; thirty years later it was named Citrus malaccensis by Ridley who expressed doubts, however, about its being a species of Citrus.

Attention was again called to the anomalous nature of this plant by I. H. Burkill (Gardens' Bull., Straits Settlem. 5:218. 1931) but he did not have any additional material, and so was unable to determine its proper taxonomic position.

Through the courtesy of R. E. Holttum, Director of the Botanic Garden of Singapore, I have been able to study the type specimen and the cotype specimen from Malacca, the only collections of this plant made up to now in the Malay Peninsula. A pistil from the type specimen was 
restored as nearly as possible to its original condition by a modification of Juel's system, then imbedded, cut into serial microtome sections that were double-stained and mounted permanently. An examination of these serial sections showed clearly that the gynaecium was very different from that of Citrus (Plate 3, figures 1,2).

The fruits of the cotype from Malacca were in such a decayed condition that it was impossible to make out the nature of the tissues found in the locules around the seeds.

Fortunately, at this juncture, Dr. E. D. Merrill called my attention to material of what he considered to be a probable new genus of the Rutaceae, that had been collected in northern Sumatra by B. A. Krukoff, and asked me to study it, generously waiving his claim to it. Fruiting specimens of Krukoff's collection, no. 4233 from Asahan, loaned to me by the New York Botanical Garden and by the Arnold Arboretum, showed at once that this Sumatran plant was the same, or very nearly the same, as the one from Malacca Territory, some 400 kilometers to the eastward across the Malacca Strait. This Sumatran material showed well-preserved ripe fruits (Plate 2) that were found to have pulp-vesicles of a new type attached to the locule walls. It was now clearly evident that this plant must be made the type of a new genus.

Burkillanthus, ${ }^{1}$ gen. nov.

Pleiospermio remote affinis, sed differt (1) loculis ovarii multiovulatis (22-24), (2) fructu multo majore, mesocarpio eximie sclerotico sub cortice tenui, (3) parietibus dorsalibus loculorum vesiculis pulpiferis magnis, sessilibus, liquido gelatinoso impletis, (4) seminibus numerosis, magnis, glabris.

Arbor ad $14 \mathrm{~m}$. alta; ramis teretibus, spinis rigidis, rectis, singulis, vel binis axillaribus instructis vel inermibus; foliis 1-2-3-foliolatis, acutis, plus minusve acuminatis; nervis primariis numerosis, utrinque 12-18, prominentibus; petiolis longitudine variabilibus, supra anguste alatis vel marginato, basi pulvinatis; floribus magnis (5-6 cm. expansis), in fasciculis paucifloribus axillaribus dispositis, 5-meris; petalis linearispatulatis; staminibus 10; pistillo longo; ovario 5-loculari, ovulis in quoque loculo numerosissimis $(22-24)$, in duobus seriebus dispositis; fructu grandi, ovoideo, cortice glanduloso, mesocarpio eximie sclerotico; loculis 5, pulpa vesiculari seminibus magnis, embryone unico.

${ }^{1}$ I am naming it Burkillanthus in honor of I. H. Burkill, former Director of the Singapore Botanical Garden, whose Dictionary of the Economic Products of the Malay Peninsula is an invaluable work of reference filled with the result of painstaking research on the plants of the Malayan region and their products. He has also published valuable notes on this plant. 
Twigs terete, glabrous, armed with stout, straight, paired or single axillary spines, or spineless (especially older fruiting twigs); leaves 3- 2- or 1-foliolate; leaflets thin, with numerous (12-18 pairs), strongly marked, subparallel, lateral veins; petioles narrowly winged or sometimes merely margined, with pulvinoid bases, variable in length, articulated with the leaflets; petiolules very short, pulvinoid; inflorescences forming few-flowered clusters in the leaf axils; flowers large, 5-merous, with 10 stamens; pedicels short, about the length of the styles; calyx deeply 5-lobed; petals 5, spathulate; gynophore cylindric, $1 / 8$ as long as the ovary; ovary obclavate, merging abruptly into the much narrower style which is nearly as long as the ovary, with 5 locules, each with 22-24 ovules arranged in 2 rows; fruits large, ovoid, more than twice as long as the longest petioles, with a thin peel dotted with numerous oil-glands covering a thin, hard woody mesocarp; pulp-vesicles numerous, broadbased and sessile (not deeply countersunk) on the dorsal locule wall, cylindrical (or subclavate?), bluntly conical at the apex, hollow (and filled with mucilage?), with rather thick, semitranslucent walls, somewhat roughened on the outside; seeds very numerous, very large, immersed in mucilaginous gum; seeds large with a thin, glabrous slightly wrinkled testa, mono-embryonic.

Burkillanthus is so distinct from any other genus of the Orange subfamily, that it must be considered as representing a rapid evolutionary development of some much simpler ancestral form that probably was somewhat like a 1-3-foliolate species of Pleiospermium, such as $P$. dubium. However, Burkillanthus has evolved into something very different from any species of Pleiospermium. Its large and very hardshelled fruits resemble in some ways those of the subtribe BALSAMoCITRINAE, but the internal structure of these fruits is strikingly different and precludes close relationship.

There are several other instances of genera in the Orange subfamily that have acquired large, more or less hard-shelled fruits, very different from those of their nearest related genera, for example Swinglea of the Philippines, Merrillia of the Malay Archipelago and Sumatra. These two genera undoubtedly are not related to each other or to Burkillanthus, but seem to represent rapid divergent evolution culminating not in a group of species or genera but, in each case, in a single aberrant monotypic genus.

Robert A. Cockrell (in Papers Mich. Acad. Sci. 20:33-36, pl. 9, 1935 ) finds the wood of Burkillanthus as it grows near Asahan, Sumatra, almost exactly like that of Micromelum pubescens, but differing decidedly from the wood of all the other genera of the Orange subfamily that 
he studied, viz.: Glycosmis, Clausena, Murraya, Merrillia, Feronia, Aegle, Atalantia and Citrus. He did not, however, have wood of Pleiospermium nor of Swinglea to compare with that of Burkillanthus.

Burkillanthus malaccensis (Ridley) Swingle, comb. nov.

Plates $2 \& 3$, Figures $1 \& 2$.

Citrus malaccensis Ridley in F1. Mal. Penin. 1: 359. 1922.

A tree up to 14 meters high, some branches with stout, straight, usually paired spines, others spineless, with leaves mostly 1- or 2-foliolate, rarely 3 -foliolate, leaflets subcoriaceous but thin, broadly lanceolate or ellipticlanceolate, acute or more or less acuminate at the tips which are blunt at the very apex; terminal leaflets and 1-foliolate leaves variable in size, often large, $12.5-27 \times 4.5-11.5 \mathrm{~cm}$., lateral leaflets much smaller, 6.5-8 $\times 3-4 \mathrm{~cm}$. with short, pulvinoid petiolules $2-2.5 \mathrm{~mm}$. long; lateral veins (of terminal leaflets) about $12-18$ on each side arising at a very wide angle $\left(70^{\circ}-85^{\circ}\right)$ with the midrib, running subparallel and only slightly curved for $2 / 3$ or $3 / 4$ of the distance from the midrib to the margin, then branching dichotomously; base broadly cuneate, articulated with the petiole by means of a pulvinoid petiolule; margin subentire, very slightly coarse-crenate; petioles of the 2- or 3-foliolate leaves $4-5 \mathrm{~cm}$. long, often narrowly winged (3-6 $\mathrm{mm}$. in total width) at apex, narrowing toward the base, often merely margined even at the apex, petioles of 1 -foliolate leaves sometimes shorter, $1-3$, rarely $4 \mathrm{~cm}$. long, sometimes almost wingless when short; inflorescences forming few- (usually 1-4-)flowered, axillary clusters; flowers large, 5-6 cm. in diam., borne on pedicels 5-7 mm. long; calyx of 5 lanceolate-acuminate, acute sepals with large oil glands, free nearly to the base; petals 5, subspathulate, with oil-glands in the broadened upper part, 20-25 mm. long, 3.5-4.5 mm. wide, tapering into a long slender base $1-1.5 \mathrm{~mm}$. wide; stamens 10 , filaments free, long, slender, anthers rather small, oblong; ovary obclavate, $6.5-7 \mathrm{~mm}$. long, $2.5 \mathrm{~mm}$. in diameter at the broadest part (about $2 / 3$ of the distance from the top of the disk to the base of the style, at a point shortly below the tips of the locules) and $1.8-2 \mathrm{~mm}$. in diameter at the base, with 5 locules, each with 22-24 ovules in 2 rows in the upper three-fourths of the locular cavity (Plate 3 , figure 2), the entire ovary covered with short sparse pubescence and with a few small oil-glands dotted over the upper half only; style slender, $5.5-6 \mathrm{~mm}$. $\times 0.5-0.7 \mathrm{~mm}$., with small oil-glands, glabrous, merging abruptly into the tip of the ovary without any definite demarcation, swelling gradually at the tip and surmounted by a depressed globose stigma without oil-glands; disk short, cylindrical, 1.4-1.5 mm. wide, 0.6-0.7 mm. high; fruits large, ovoid, $10-11 \times 8-9 \mathrm{~cm}$., outer peel 
thin (2-3 mm.), roughened with numerous slightly depressed oil-glands, fitting closely on a woody mesocarp 2-3 mm. thick, very hard in dried fruits, that shows on its outer surface numerous slightly depressed areas 1.5-3 mm. diameter; pulp vesicles 5-12 (or more ?) mm. long and about 1.5-3 mm. wide, sac-like, cylindrical, broad-based and sessile but apparently only very slightly imbedded in the locule wall. These pulp-vesicles are not stalked, near the tip they taper abruptly into a blunt conical apex. They seem to have a semitranslucent, rather thick wall, rough on the outside and are perhaps hollow and full of mucilage. No similar pulp-vesicles are known in any other genus of citrous fruit yet studied. The locules of the ripe fruit are almost filled with large seeds, apparently imbedded in mucilaginous gum, perhaps secreted by the rudimentary pulp-vesicles; the seeds are large, broadly obovate, tapering to an acute point at the base where the seed is attached, $22-27 \times 16 \times 7-10 \mathrm{~mm}$., mono-embryonic with pale buff (not green) cotyledons, testa thin, papery, irregularly wrinkled when dried.

Type: Malay Peninsula, Malacca, Nyalas, Goodenough no. 1273 (Herb. Bot. Gard. Singapore); Serial microtome sections, S. and T., slides $223 \mathrm{~A}, 1-10$ (cross section of pistil), $244 \mathrm{~A},-1,0,1-4$ (longitud. sect. of pistil), filed in type collection, Herb. Nat. Arboretum, Washington. Paratype: Malacca, Bukit Sadanan Derry no. 1106 (Herb. Bot. Gard. Singapore); Asahan, North Sumatra, Krukoff no. 4233 (Herb. N. Y. Bot. Gard. and Herb. Arnold Arboretum). Common name: Malay Ghost-lime (limau hantu), Sumatran djeroek oetan.

Possible uses: This striking tree is without doubt a member of the subtribe Citrinae and very possibly is nearly enough related to Citrus to be used as a root-stock for it. Burkillanthus has numerous seeds which, because of their large size, should provide the young seedling with abundant nourishment. Very vigorous seedlings should be produced and tested as root-stocks. Now that Burkillanthus has been rediscovered in northern Sumatra, it is to be hoped that it can be introduced into culture.

Pleiospermium (Engl.) Swingle, in Jour. Wash. Acad. Sci., 6: 426.1916.

Limonia Sect. Pleiospermium Engl. Nat. Pflanzenfam. III. 4: 189. 1896.

This genus, when I established it in 1916, included P. alata (Wight $\&$ Arn.) Swingle of India and Ceylon, the type species with 3 -foliolate leaves and the polymorphic P. dubium (Blume) Swingle of Java with 12 - or 3 -foliolate leaves with petioles varying decidedly in length, with single or paired spines in the axils of the leaves or spineless.

The three new species here described all have 1 -foliolate leaves with more or less broadly winged petioles and in their leaf characters resemble somewhat the 1 -foliolate forms of $P$. dubium. 
The well developed winged petioles of Pleiospermium that are always articulated with the leaf-blade, resemble those of Burkillanthus (which has, however, very different flowers and fruits), and are also not unlike those of Citrus and Poncirus. The pulp-vesicles of Pleiospermium are of a primitive type, varying decidedly in form, size and structure in the different species. They show a more or less well-differentiated outer cortical layer surrounding a central portion that seems to disintegrate on maturity much like the cellular contents of the oil-glands found in all the superficial tissues of the Rutaceae. None of the species of Pleiospermium have broad-based conical pulp-vesicles like Atalantia and Citropsis, nor slender-stalked juicy pulp-vesicles like Citrus.

Nevertheless, these latter genera having more specialized pulp-vesicles may well have developd from remote ancestral Pleiospermium-like forms.

Pleiospermium longisepalum, sp. nov.

Plate 3, Figure 5.

Pleiospermio dubio affine, sed differt (1) foliis semper 1-foliolatis, (2) lobis sepalorum gracilibus, longissimis (9-12 mm.), reflexis.

Arbor parva vel arbuscula, ramulis gracilibus (2-3 mm. diam.), junioribus angularibus, inermibus (in ramulis fructiferis); foliis 1-foliolatis, laminis 75-115 × 30-45 mm., ellipticis, integris, apice acuminatis, nervis lateralibus obscuris, utrinque 8-10; petiolis 10-12 mm., anguste alatis (ala $1 / 2-2 / 3 \mathrm{~mm}$. lata); floribus singulis in axillis foliorum, ramulis florentibus apice in inflorescentiam racemosam sine foliis vel cum foliis reductis transientibus; pedicellis $20-25 \times 1.5-2 \mathrm{~mm}$., bracteis minutis instructis (pedicellis florum sterilium persistentibus, gracilibus, 15-20 $\times$ 0.75-1 mm.); sepalis persistentibus, griseo-viridibus, liguliformibus, 9-12 mm. longis, basi $2 \mathrm{~mm}$. latis, apice $0.5-0.8 \mathrm{~mm}$. latis et obtuse rotundatis vel paulo emarginatis, rectis et valde reflexis sub fructu maturante, intus unum nervum medium exhibentibus, integris; fructibus ovoideis, glabris, griseo-viridibus, $20 \times 15 \mathrm{~mm}$., 3-locularibus cum 1-2 ovulis in quoque loculo, vesiculis pulpiferis rudimentariis, corticatis, ellipticis, 4-6 mm. longis, e parietibus dorsalibus loculorum nascentibus, apice obtusis; fructus cortice tenui $(1-1.5 \mathrm{~mm}$.), numerosis glandulis oleiferis minutis instructo; seminibus $1-2$, circiter $11 \times 6 \times 4 \mathrm{~mm}$., embryone unico.

Borneo: Banguey Island, about $11 \mathrm{~km}$. off the extreme northeast point of Borneo and about $50 \mathrm{~km}$. south of Palawan, the westernmost large island of the Philippines, Castro and Melegrito 1348. (Type in Herb. Nat. Arboretum, no. 45800; isotype in Herb. Arnold Arboretum; paratype Castro and Melegrito, 1713, in Herb. Univ. Calif.) 
Dr. E. D. Merrill in a paper "The Flora of Banguey Island" (Phil. Jour. Sci. 29:377. 1926) lists it as “Atalantia sp.?” but says: "The sepals are linear or strap-shaped, free, persistent, $1 \mathrm{~cm}$. long and about $1.5 \mathrm{~mm}$. wide, in this character differing from both Citrus and Atalantia." After mentioning that I had found in the fruits pulp-vesicles differing essentially from those of Citrus, he says: "Perhaps an undescribed genus is represented here."

Recently in making a close study of Pleiospermium, it became evident that this plant was an aberrant species of this genus with 1 -foliolate leaves very like Citrus and fruits very like those of $P$. dubium, containing similar primitive corticate pulp-vesicles. The extraordinary elongate strap-shaped sepals which become reflexed after anthesis and persist until after the ripe fruits fall off, are a new and very striking character not found on such a grand scale in any other species of the 200 and more belonging to the Orange subfamily. Shorter persistent sepals are found in P. latialatum.

Pleiospermium dubium of Java often has unifoliolate leaves on old trees that are much like those of $P$. longisepalum, even to showing frequently a narrow wing on the upper portion of the petiole.

Pleiospermium sumatranum, sp. nov.

Plate 3, figures 3, 4.

Plsiospermio dubio affine, sed differt (1) foliis semper 1-foliolatis, (2) foliolis majoribus, acuminato-caudatis, (3) petiolis distincte alatis, (4) vesiculis pulpiferis minutis (1-2 mm. longis).

Arbor vel arbuscula, ramulis fructiferis inermibus, gracilibus, 1-2 mm. diam.; foliis 1-foliolatis, laminis magnis, $1-7 \times 5-6.5 \mathrm{~cm}$., rotundate lanceolatis, acuminato-caudatis, acumine 9-13 mm. longo, deorsum 3-4.5 $\mathrm{mm}$. lato, sursum i-2 mm. lato, apice abrupte minute emarginato; nervis primariis utrinque 10-12; petiolis $18-20 \mathrm{~mm}$. longis, alatis, apice 3.5-6.5 $\mathrm{mm}$. latis, basi apteris, 4-5 mm. latis; floribus ignotis; calycibus persistentibus, 5-lobis, lobis 2-2.2 mm. longis, 1-2 mm. latis; fructu subgloboso, 18-20 diam., 3-loculari, loculo quoque vesiculis pulpiferis numerosissimis minutis, $1-2 \mathrm{~mm}$. longis et $0.4-0.7 \mathrm{~mm}$. latis, apice rotundatis mucilagine translucente impletis instructo.

Sumatra: Korthals no. S960 (Type in Rijksherbarium, Leiden, sheet no. "908,204- . . 137"); Sumatra, Paanus, Korthals no. S 960 (paratype in Rijksherbarium, Leiden, sheet no. "908,204- . . 132"). Probably a Sumatran specimen labeled "Herb. Korthals?" in Rijksherbarium, Leiden, sheet no. "908,203- . . 210" is also this species. Known only from this collection. 
This species of Pleiospermium has the dorsal walls of the three locules of the fruit lined with remarkably small pulp-vesicles which are very numerous, ovoid, bluntly rounded at the tips, 1-2 $\mathrm{mm}$. long, 0.4-0.7 $\mathrm{mm}$. wide, slightly narrowed at the base but not imbedded in the locule wall, cortex very thin, composed of indistinct cells, contents sharply delimited from the cortical layer, decomposing into a spongy (?) mass of oily or mucilaginous matter looking almost exactly like the contents of the oilglands in the peel of immature fruit (Plate 3, figure 4). Apparently these very small pulp-vesicles secrete a translucent liquid that completely fills the locules of the fruit. In dried herbarium specimens this liquid hardens to a dark reddish brown mass that splinters when struck a sharp blow.

Pleiospermium sumatranum resembles $P$. dubium in having small pulpvesicles but differs in having only 1 -foliolate, larger, more acuminatecaudate leaves that are much like those of $P$. longisepalum and P. latialatum and not unlike those of Citrus except in being acuminate-caudate.

Pleiospermium latialatum, sp. nov.

Plate 3, figure 6.

Pleiospermio longisepalo affine, sed differt (1) foliis majoribus, acuminato-caudatis, (2) petiolis late alatis, alis cordatis $(1.6-2.4 \times 1-2$ $\mathrm{cm}$.), (3) lobis calycis angustis, triangularibus 4-6 $\times 2-3 \mathrm{~mm}$., cuneatis, persistentibus, reflexis usque $90^{\circ}$ ad pedicellum.

Arbor parva vel arbuscula, ramulis inermibus, ultimis gracilibus (1-2 mm. diam.), primo paulo angulatis, demum teretibus; foliis 1-foliolatis, laminis 9-15 × 3.5-7 cm., glabris, oblongo-ellipticis vel lanceolatis, apice acuminato-caudatis, acumine lineari 4-6 mm. longo, 1.5-2 mm. lato, emarginato, nervis lateralibus utrinque 10-13; petiolis late alatis, cordatis, $1.6-2.4 \times 1-2 \mathrm{~cm}$., basi angustatis, pulvinoideis, minute striatis, supra canaliculatis; floribus ignotis; calycis extus puberulentis lobis anguste triangularibus vel apice plus minusve rotundatis, 2-4 mm. longis, $2.5 \mathrm{~mm}$. latis, sub fructu juniore persistentibus reflexis usque $90^{\circ}$ ad pedicellum; fructu globoso, 10-14 mm. diam., glabro, cortice viridi, rugoso, glandulis oleiferis crateriformibus numerosis instructo; loculis 3 , ad parietes dorsales vesiculis pulpiferis gracillimis $3-4.5 \mathrm{~mm}$. longis acutis indistincte corticatis instructis; seminibus 2 vel 3 , magnis, crassis.

Pulp-vesicles slender, conical often ending in a blunt point at the apex 3-4.5 mm. long. The cortical tissue is much thinner than in P. dubium and the contents do not break up as completely. The bases of the pulpvesicles are not so deeply sunken into the dorsal locule walls as in Atalantia or Citropsis. 
Borneo: Elphinstone Province, Tawao. British North Borneo, Elmer no. 21542 (Herb. Arnold Arboretum). Known only from the type collection.

This species is clearly related to $P$. longisepalum but differs in so many characters that it appears to be a good species. The leaves look surprisingly like Citrus, but the twigs (at least the fruiting ones) are spineless. It is of especial interest as it looks as if it might be a remote ancestor of Citrus although its fruits show only rudimentary pulp-vesicles.

This species with $P$. longisepalum, $P$. dubium and $P$. alatum, constitute a remarkable series: $P$. alatum with always 3 -foliolate, $P$. dubium with 1 - or 2 -foliolate, but occasionally 3 -foliolate leaves, $P$. longisepalum with 1 -foliolate leaves with narrowly winged petioles, and finally P. latialatum with 1 -foliolate leaves with broadly winged petioles much like some forms of Citrus Aurantium. The pulp-vesicles in this series progress from the short, thickly corticated ones of $P$. dubium to the slender-conical, acute-pointed ones of $P$. latialatum. Much light will doubtless be thrown on the origin and development of pulp-vesicles by a critical study of living material of these and other species of Pleiospermium.

\section{EXPLANATION OF PLATES}

\section{Plate 1}

Clymenia polyandra (Tanaka) Swingle. Figures 1, 2, 3, type specimen in Herb. Berlin-Dahlem. Figures 4, 5, 6, topotype, Coll. Gee, 5/6/37, preserved in formaldehyde solution.

Figure 1. 1/5 nat. size.

Figure 2. Sections of flower bud. $\times 5$.

Figure 3. Flower buds and pistil. $\times 1 \frac{1}{2}$.

Figure 4. Section of ripe fruit. Nat. size.

Figure 5. Ripe fruit. Nat. size.

\section{Plate 2}

Burkillanthus malaccensis (Ridl.) Swingle. Leafy twig, spines and fruit sections, Coll. Krukoff, Asahan, Sumatra. Nat. size.

$$
\text { Plate } 3
$$

\section{Burkillanthus malaccensis}

Figure 1. Type specimen from Malacca Territory. Two axillary flowers. Nat. size.

Figure 2. Nine serial sections of the pistil in Figure 1. $\times 2$. 

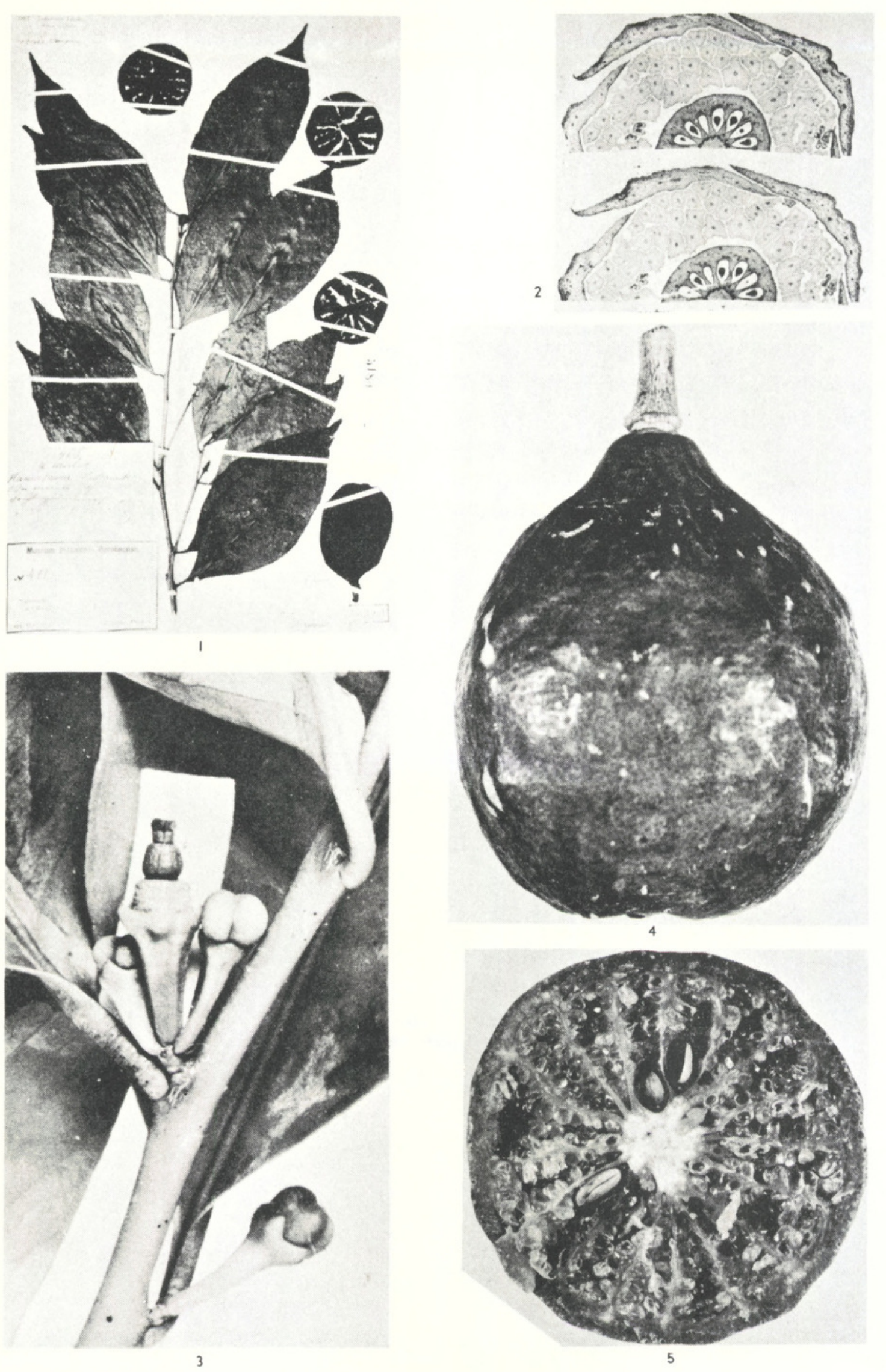

Clymenia Polyandra (Tanaka) Swingle 


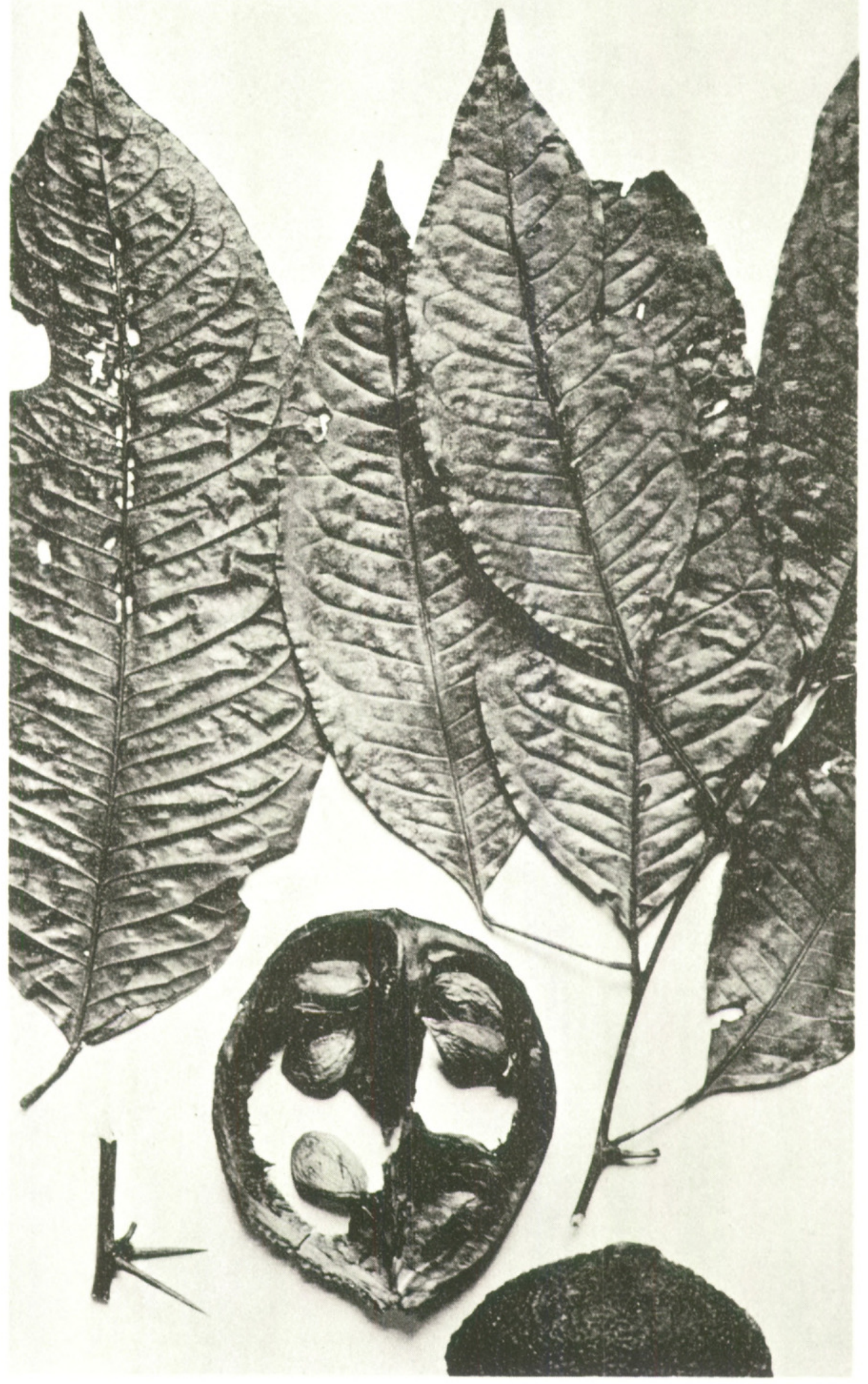

Burkillanthus malaccensis (Ridley) Swingle 

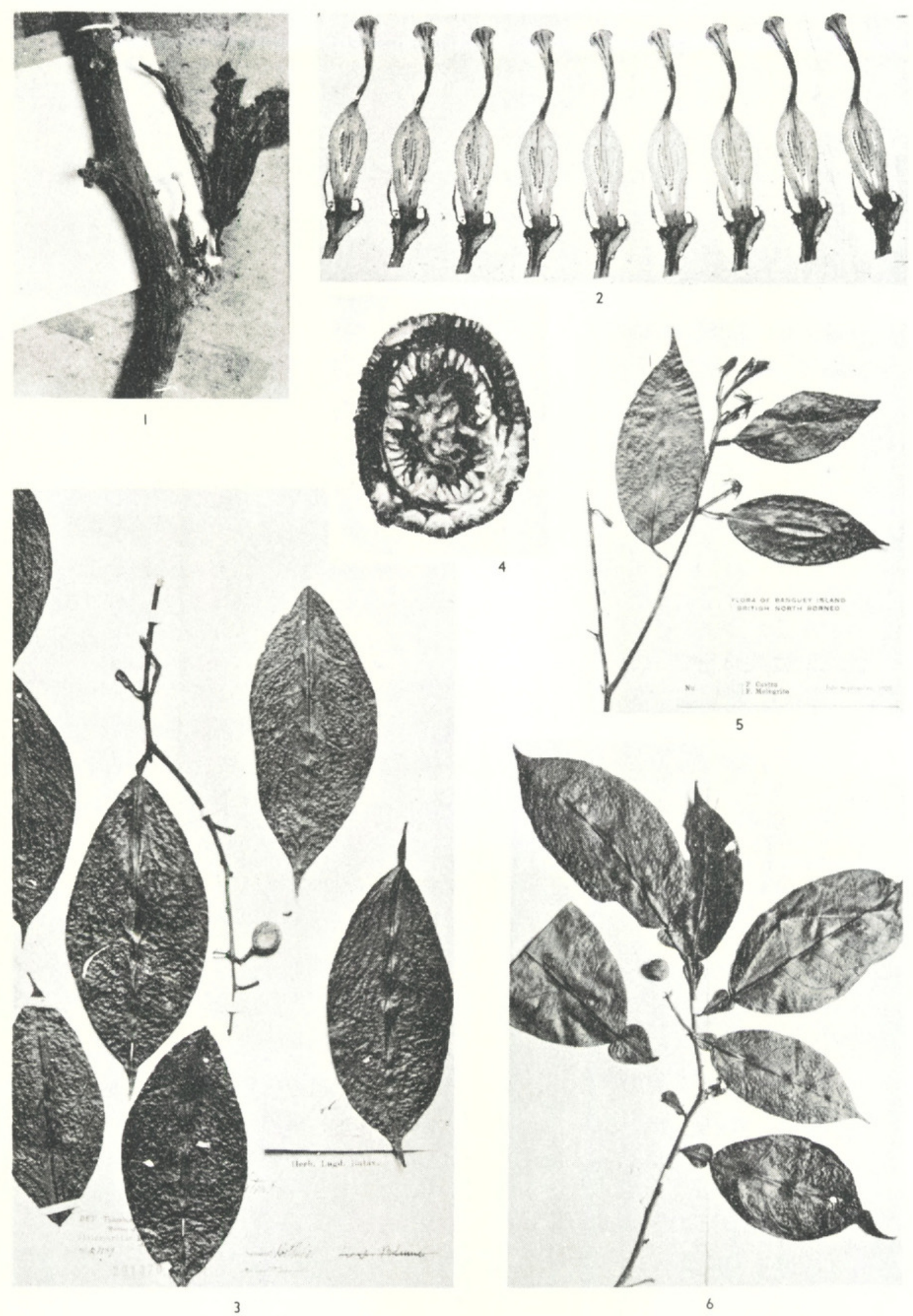

Burkillanthus malaccensis (Ridley) Swingle, Pleiospermium Sumatranum Swingle, P. LONGiSEPalum Swingle and P. latialatum Swingle 


\section{$2 \mathrm{BHL}$ Biodiversity Heritage Library}

Swingle, Walter T. 1939. "Clymenia and Burkillanthus, New Genera Also Three New Species of Pleiospermium (Rutaceae-Aurantioideae)." Journal of the Arnold Arboretum 20(2), 250-263. https://doi.org/10.5962/p.185415.

View This Item Online: https://www.biodiversitylibrary.org/item/33596

DOI: https://doi.org/10.5962/p.185415

Permalink: https://www.biodiversitylibrary.org/partpdf/185415

\section{Holding Institution}

Missouri Botanical Garden, Peter H. Raven Library

\section{Sponsored by}

Missouri Botanical Garden

\section{Copyright \& Reuse}

Copyright Status: In copyright. Digitized with the permission of the rights holder.

Rights Holder: Arnold Arboretum of Harvard University

License: http://creativecommons.org/licenses/by-nc-sa/3.0/

Rights: https://biodiversitylibrary.org/permissions

This document was created from content at the Biodiversity Heritage Library, the world's largest open access digital library for biodiversity literature and archives. Visit BHL at https://www.biodiversitylibrary.org. 